\title{
Research on Inventory Technology of Talents in State-owned Enterprises
}

\author{
Wang $\operatorname{Han}^{1 *}$, Xu Yunfei ${ }^{1}$, Wang Dan ${ }^{1}$ \\ ${ }^{1}$ State Grid Energy Research Institute Co.,Ltd., Beijing, China
}

\begin{abstract}
Based on the in-depth analysis of the strategic needs of state-owned enterprises, this paper establishes a key talent competency model and builds a talent inventory model. It describes in detail the use of talent inventory related technologies in practice and the evaluation and analysis of the content and indicators involved in talent inventory. It provides an effective reference and reference for state-owned enterprises to carry out talent inventory.
\end{abstract}

\section{Introduction}

Talent inventory is a detailed investigation and analysis of the overall situation of human resources. It comprehensively evaluates talents through analysis of their thinking, experience, skills, and performance. The four core technologies are competence technology, evaluation technology, development technology and information technology[1].

The purpose of talent inventory can be divided into organizational perspective and employee perspective. From an organizational perspective, talent inventory is to find internal talents, establish a talent system, and provide a basis for human resources decision-making around the company's development strategy[2]. From the perspective of individual employees, talent inventory is to promote employees to establish a clear career development direction, encourage employees to grow better, and implement the landing human resource decision-making plan.

\section{Talent inventory model construction}

The development goals of state-owned enterprises require that the talent team is fully matched with it, and the job orientation and job match of the talent team can also promote employees to give full play to their professional abilities and potential levels and improve work performance[3]. Therefore, this article combines the needs of talent inventory to form the performancepotential matrix inventory technical requirements, and sets five categories for the state-owned enterprise talent inventory model: political quality, professional ability, performance level, potential level, and professional orientation. Set different dimensions for the rich political quality and professional ability categories, and further subdivide the dimensions of the more comprehensive professional ability categories, and set relevant elements.

TABLE I. TALENT INVENTORY MODEL FRAMEWORK

\begin{tabular}{|c|c|c|c|}
\hline Category & Dimension & Element & Evaluation Tool \\
\hline \multirow{6}{*}{ Political Quality } & Political Beliefs & \multirow{6}{*}{-} & \multirow{6}{*}{$\begin{array}{c}\text { Self-Developed } \\
\text { Scale }\end{array}$} \\
\hline & Political Loyalty & & \\
\hline & Political Responsibility & & \\
\hline & $\begin{array}{l}\text { Political } \\
\text { Self-discipline }\end{array}$ & & \\
\hline & Political Ability & & \\
\hline & National Sentiments & & \\
\hline \multirow{7}{*}{ Professional Ability } & \multirow{2}{*}{ Leadership } & Team Leader & \multirow{7}{*}{$\begin{array}{l}\text { Self-Developed } \\
\text { Scale }\end{array}$} \\
\hline & & Strategic Planning & \\
\hline & \multirow{5}{*}{ Management Ability } & Executive Ability & \\
\hline & & Decision-Making Capacity & \\
\hline & & Training Guidance & \\
\hline & & Influence Capacity & \\
\hline & & Organization & \\
\hline
\end{tabular}

\footnotetext{
* Corresponding author: wanghan@sgeri.sgcc.com.cn
} 


\begin{tabular}{|c|c|c|c|}
\hline \multirow[t]{6}{*}{ Category } & Dimension & Element & Evaluation Tool \\
\hline & \multirow{5}{*}{ Professional Quality } & \& Coordination & \\
\hline & & Professional & \\
\hline & & Performance-Oriented & \\
\hline & & Cost Awareness & \\
\hline & & Customer Orientation & \\
\hline Performance Level & - & 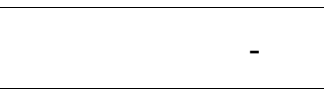 & $\begin{array}{l}\text { Annual Assessment } \\
\text { Results }\end{array}$ \\
\hline Potential Level & - & - & $\begin{array}{l}\text { Classic Maturity } \\
\text { Scale }\end{array}$ \\
\hline $\begin{array}{l}\text { Professional } \\
\text { Orientation }\end{array}$ & - & - & $\begin{array}{l}\text { Classic Maturity } \\
\text { Scale }\end{array}$ \\
\hline
\end{tabular}

For the setting of category weights, the political quality, professional ability and performance level weights are each $50 \%$ combined into the performance of key talents. Among them, political quality is $20 \%$ and professional ability is $30 \%$. The potential level is the category tested separately in the talent inventory, and the weight is $100 \%[4]$.

TABLE II. THE WEIGHT AND CONNOTATION OF THE INVENTORY CATEGORY OF THE TALENT INVENTORY MODEL

\begin{tabular}{|l|c|l|}
\hline Category & Weights & \multicolumn{1}{c|}{ Connotation } \\
\hline Political Quality & $20 \%$ & $\begin{array}{l}\text { The firm and correct political direction and political } \\
\text { beliefs necessary to engage in work responsibilities, as } \\
\text { well as the comprehensive performance of the company's } \\
\text { party committee. }\end{array}$ \\
\hline $\begin{array}{l}\text { Professional } \\
\text { Ability }\end{array}$ & $30 \%$ & $\begin{array}{l}\text { The ability to perform a certain task outstandingly is } \\
\text { formed by the use of knowledge and skills in the transfer } \\
\text { and integration of business management and research } \\
\text { activities. }\end{array}$ \\
\hline $\begin{array}{l}\text { Performance } \\
\text { Level }\end{array}$ & $50 \%$ & $\begin{array}{l}\text { In a certain period of time in the company, complete } \\
\text { descriptive work behaviors and measurable work results } \\
\text { and work effectiveness levels. }\end{array}$ \\
\hline Potential Level & $100 \%$ & $\begin{array}{l}\text { The ability to transform the knowledge and wisdom you } \\
\text { have, plus the experience you have experienced, into } \\
\text { performance in a new situation or changing environment. }\end{array}$ \\
\hline $\begin{array}{l}\text { Professional } \\
\text { Orientation }\end{array}$ & - & $\begin{array}{l}\text { A stable professional behavior tendency suitable for the } \\
\text { company's job category formed on the basis of } \\
\text { professional evaluation. }\end{array}$ \\
\hline
\end{tabular}

\section{Self-developed scale dimensions and elements}

\subsection{Political Quality}

From the perspective of General Secretary Xi Jinping's requirements for the political quality of party members in the new era, political quality includes at least five aspects: political ideals and beliefs, political loyalty, political style, political responsibility, and political ability. In addition, employees are the foundation of the company's development, the company is an extension of employee development, and the height of the employee's personal career development. The research team in this article adds the dimension of family and country feelings to the political quality[5]. In these six dimensions, political belief is the fundamental element that determines the motivation and direction of talent development, so the weight is slightly higher.

TABLE III. THE WEIGHT AND CONNOTATION OF POLITICAL QUALITY

\begin{tabular}{|l|c|l|}
\hline Category & Weights & \multicolumn{1}{c|}{ Connotation } \\
\hline Political Beliefs & $20 \%$ & $\begin{array}{l}\text { Full of confidence in the socialist road, resolutely } \\
\text { safeguard the decision and deployment of the Party } \\
\text { Central Committee, firm political convictions and use } \\
\text { their words and deeds to influence those around them. }\end{array}$ \\
\hline Political Loyalty & $16 \%$ & $\begin{array}{l}\text { Strictly implement the decision-making and deployment } \\
\text { of the company's party committee, with unanimous heart, } \\
\text { consistent with the outside and inside, and implement } \\
\text { high standards and strict requirements for work. }\end{array}$ \\
\hline
\end{tabular}




\begin{tabular}{|l|c|l|}
\hline Category & Weights & \multicolumn{1}{c|}{ Connotation } \\
\hline $\begin{array}{l}\text { Political } \\
\text { Responsibility }\end{array}$ & $16 \%$ & $\begin{array}{l}\text { Keep in mind the mission of state-owned enterprises, } \\
\text { perform your duties for the party, be brave enough to face } \\
\text { difficulties and problems, be pioneering and enterprising, } \\
\text { and dare to take responsibility. }\end{array}$ \\
\hline $\begin{array}{l}\text { Political } \\
\text { Self-discipline }\end{array}$ & $16 \%$ & $\begin{array}{l}\text { Have a strong sense of political discipline and political } \\
\text { rules, consciously implement the "Eight Regulations". }\end{array}$ \\
\hline Political Ability & $16 \%$ & $\begin{array}{l}\text { Focus on the overall situation of enterprise development, } \\
\text { be good at managing the work situation, have strong } \\
\text { political risk prevention capabilities, and be able to } \\
\text { accurately grasp the work direction and general trend. }\end{array}$ \\
\hline $\begin{array}{l}\text { National } \\
\text { Sentiments }\end{array}$ & $\begin{array}{l}\text { Follow the company's party committee deployment, } \\
\text { agree with the company's corporate culture and mission, } \\
\text { have the ideas and concepts that promote the company's } \\
\text { development, and believe that its own development and } \\
\text { the company's development are mutually related and } \\
\text { integrated. }\end{array}$ \\
\hline
\end{tabular}

\subsection{Professional Ability}

According to the iceberg model, the competency model in the talent inventory model of this research has set 6 quality dimensions, under which specific elements are set, and each element is divided into different behavior levels[6].

TABLE IV. THE WEIGHT AND CONNOTATION OF PROFESSIONAL COMPETENCE

\begin{tabular}{|c|c|c|c|c|}
\hline Category & $\begin{array}{c}\text { Category } \\
\text { Weights }\end{array}$ & Element & $\begin{array}{l}\text { Element } \\
\text { Weights }\end{array}$ & Element Connotation \\
\hline \multirow{2}{*}{ Leadership } & \multirow{2}{*}{$30 \%$} & $\begin{array}{l}\text { Team } \\
\text { Leader }\end{array}$ & $50 \%$ & $\begin{array}{l}\text { Give full play to the advantages of team members } \\
\text { through authorization, incentives and other } \\
\text { management methods, promote teamwork, resolve } \\
\text { personnel conflicts, and lead team members to } \\
\text { complete work goals. }\end{array}$ \\
\hline & & $\begin{array}{l}\text { Strategic } \\
\text { Planning }\end{array}$ & $50 \%$ & $\begin{array}{l}\text { Track and analyze changes in the external market } \\
\text { environment and the matching of strategic goals, } \\
\text { formulate mid- and long-term development goals, } \\
\text { and make feedback adjustments and suggestions to } \\
\text { superiors based on the implementation. }\end{array}$ \\
\hline \multirow{3}{*}{$\begin{array}{l}\text { Manageme } \\
\text { nt Ability }\end{array}$} & \multirow{3}{*}{$40 \%$} & $\begin{array}{l}\text { Executive } \\
\text { Ability }\end{array}$ & $20 \%$ & $\begin{array}{l}\text { Develop a clear work plan and feedback mechanism, } \\
\text { be ready to deal with various obstacles and problems } \\
\text { at any time, and all work can meet the requirements } \\
\text { of the superior and exceed the expectations of the } \\
\text { superior. }\end{array}$ \\
\hline & & $\begin{array}{l}\text { Decision- } \\
\text { Making } \\
\text { Capacity }\end{array}$ & $20 \%$ & $\begin{array}{l}\text { Through the analysis and judgment of multiple } \\
\text { feasible solutions, the ability to select the most } \\
\text { appropriate solution and implementation time, and } \\
\text { be able to take risks courageously, and make clear } \\
\text { decisions that are conducive to advancing the work. }\end{array}$ \\
\hline & & $\begin{array}{l}\text { Training } \\
\text { Guidance }\end{array}$ & $20 \%$ & $\begin{array}{l}\text { Have the willingness to train others, by paying } \\
\text { attention to the potential and plasticity of } \\
\text { subordinates, providing correct guidance and } \\
\text { necessary support for the work of subordinates, and } \\
\text { improving their work performance ability by sharing }\end{array}$ \\
\hline
\end{tabular}




\begin{tabular}{|c|c|c|c|c|}
\hline Category & $\begin{array}{c}\text { Category } \\
\text { Weights }\end{array}$ & Element & $\begin{array}{l}\text { Element } \\
\text { Weights }\end{array}$ & Element Connotation \\
\hline & & & & $\begin{array}{l}\text { experience with subordinates and evaluating } \\
\text { feedback. }\end{array}$ \\
\hline & & $\begin{array}{l}\text { Influence } \\
\text { Capacity }\end{array}$ & $20 \%$ & $\begin{array}{l}\text { The ability to use data, facts, and other direct } \\
\text { influence methods, or through indirect strategies } \\
\text { such as interpersonal relationships and personal } \\
\text { charm, to influence others to make them accept their } \\
\text { own opinions or make them produce expected } \\
\text { behaviors. }\end{array}$ \\
\hline & & $\begin{array}{l}\text { Organizati } \\
\text { on } \\
\& \\
\text { Coordinati } \\
\text { on }\end{array}$ & $20 \%$ & $\begin{array}{l}\text { According to the needs of the work objectives, the } \\
\text { ability to rationally allocate relevant resources, } \\
\text { coordinate the relations of all parties, mobilize the } \\
\text { enthusiasm of all parties, and promptly handle and } \\
\text { solve various problems in the process of achieving } \\
\text { the goals. } \\
\text { Element connotation. }\end{array}$ \\
\hline \multirow{4}{*}{$\begin{array}{l}\text { Profession } \\
\text { al Quality }\end{array}$} & \multirow{4}{*}{$30 \%$} & $\begin{array}{l}\text { Profession } \\
\text { al }\end{array}$ & $25 \%$ & $\begin{array}{l}\text { Pay attention to new technologies, new methods and } \\
\text { other professional frontier information, as well as } \\
\text { new theories and frontier dynamics in the } \\
\text { professional field, keep in close contact with the } \\
\text { frontiers and accurately evaluate future development } \\
\text { trends, and at the same time put forward suggestions } \\
\text { related to company strategy. }\end{array}$ \\
\hline & & $\begin{array}{l}\text { Performan } \\
\text { ce- } \\
\text { Oriented }\end{array}$ & $25 \%$ & $\begin{array}{l}\text { Performance orientation is to use results as the main } \\
\text { basis for measuring work effectiveness; focus on } \\
\text { improving performance, achieving goals and output } \\
\text { results. }\end{array}$ \\
\hline & & $\begin{array}{l}\text { Cost } \\
\text { Awareness }\end{array}$ & $25 \%$ & $\begin{array}{l}\text { Under the premise of ensuring normal working } \\
\text { conditions and product quality, the company } \\
\text { maximizes profits by controlling costs, increasing } \\
\text { output, and optimizing processes. }\end{array}$ \\
\hline & & $\begin{array}{l}\text { Customer } \\
\text { Orientation }\end{array}$ & $25 \%$ & $\begin{array}{l}\text { Able to pay attention to the changing needs of } \\
\text { external customers, and do their best to help and } \\
\text { serve customers, and create value for customers. }\end{array}$ \\
\hline
\end{tabular}

\subsection{Performance Level}

The performance level is generally based on the annual performance appraisal results obtained by the state-owned enterprise appraisal system. In the process of talent inventory, the company's performance can be converted into corresponding scores and distinguished into three levels: high, medium and low[7].

\section{Classic Maturity Scale Dimensions and Elements}

\subsection{Potential Level}

Potential talents are those who have the willingness to lead, the ability to achieve success, and a higher degree of dedication to the organization while maintaining high performance. This article uses representative and highly popular learning acuity to represent the potential of key talents[8]. Generally, talents with high learning acumen have high potential and are more likely to succeed after 
being promoted. If the personality matches the needs of the position, the potential advantage will be more obvious.

TABLE V. DIMENSION AND CONNOTATION OF LEARNING ACUITY

\begin{tabular}{|l|l|}
\hline Category & \multicolumn{1}{c|}{ Connotation } \\
\hline $\begin{array}{l}\text { Mental } \\
\text { acuity }\end{array}$ & $\begin{array}{l}\text { Good at thinking, willing to deal with } \\
\text { complex problems, examining problems } \\
\text { in unconventional and unique way, } \\
\text { seeking knowledge and exploring new } \\
\text { ideas, and establishing new connections } \\
\text { between different concepts. }\end{array}$ \\
\hline $\begin{array}{l}\text { Interpers } \\
\text { onal } \\
\text { acuity }\end{array}$ & $\begin{array}{l}\text { Treat others with an open attitude, like to } \\
\text { interact with all kinds of people, } \\
\text { understand the unique strengths and } \\
\text { interests and shortcomings of others, and } \\
\text { make full use of others to achieve } \\
\text { organizational goals. }\end{array}$ \\
\hline $\begin{array}{l}\text { Change } \\
\text { acuity }\end{array}$ & $\begin{array}{l}\text { Likes to change, constantly explores new } \\
\text { solutions and solutions, and is keen to } \\
\text { lead organizational changes. }\end{array}$ \\
\hline $\begin{array}{l}\text { Result } \\
\text { acuity }\end{array}$ & $\begin{array}{l}\text { Inspiring the team and exerting influence } \\
\text { can create results in the case of first-time } \\
\text { problems. }\end{array}$ \\
\hline $\begin{array}{l}\text { Self- } \\
\text { knowledg able to perceive yourself, clearly } \\
\text { e }\end{array}$ & $\begin{array}{l}\text { understand your strengths and } \\
\text { weaknesses, eliminate blind spots, and } \\
\text { use your knowledge of yourself to work } \\
\text { efficiently. }\end{array}$ \\
\hline
\end{tabular}

\subsection{Professional Orientation}

Occupational orientation refers to the employee's professional interests and the scope of work that is relatively suitable[9]. The classification of occupational orientation is to classify many complex occupations into a limited number of occupational groups with a reasonable division, and help the testees find the most interesting or suitable occupation field. In the talent inventory, clarifying the employee's career orientation is conducive to evaluating and planning the employee's job match and career development direction. The occupational orientation studied in this article is based on the 16 occupational categories classified by MyersonBriggs on occupational orientation: inspector type, caregiver type, fraternity type, expert type, adventurer type, artist type, philosopher type, scholar type, challenger type, performer type, public relations type, smart star type, housekeeper type, master type, teaching type , commander type[10].

The scale has been set up as "judgment vs perception", "thinking vs emotion", "feeling vs intuition", "extraversion vs introversion" and other control groups. According to the comparison score to judge the professional tendency, at the same time dock the company's key talent inventory range of job characteristics. According to the evaluation results, the professional tendency of each key talent individual and the matching with the existing positions can be obtained, so as to better promote the work efficiency of the matching of personnel and positions.

\section{$5 \quad$ Path and method of generating key talent inventory report}

In the process of key talent inventory, the performance of key talents-potential nine square grid is the main result that needs to be presented in the end. According to the key talent inventory model, the generation path of the key talent inventory report is shown in the following table.

TABLE VI. TALENT INVENTORY ADOPTION METHODS AND CORRESPONDING INVENTORY RESULTS

\begin{tabular}{|c|c|c|c|}
\hline $\begin{array}{l}\text { Evaluation } \\
\text { Item }\end{array}$ & $\begin{array}{c}\text { Correspon } \\
\text { ding } \\
\text { Category }\end{array}$ & $\begin{array}{l}\text { Evaluatio } \\
\text { n Method }\end{array}$ & $\begin{array}{c}\text { Corresponding to } \\
\text { the Content of the } \\
\text { Talent Inventory } \\
\text { Report }\end{array}$ \\
\hline \multirow{3}{*}{$\begin{array}{l}\text { Performanc } \\
\text { e Level }\end{array}$} & $\begin{array}{l}\text { Political } \\
\text { Quality }\end{array}$ & $\begin{array}{c}360 \\
\text { Degree }\end{array}$ & \multirow{3}{*}{$\begin{array}{c}\text { Jiugongge } \\
\text { Ordinate } \\
\text { Personal } \\
\text { Performance } \\
\text { Ability-Potential } \\
\text { Report }\end{array}$} \\
\hline & $\begin{array}{l}\text { Profession } \\
\text { al Ability }\end{array}$ & $\begin{array}{c}\text { Evaluatio } \\
\mathrm{n}\end{array}$ & \\
\hline & $\begin{array}{l}\text { Performan } \\
\text { ce Level }\end{array}$ & $\begin{array}{l}\text { Performa } \\
\text { nce } \\
\text { Appraisal } \\
\text { Results }\end{array}$ & \\
\hline Potential & $\begin{array}{l}\text { Potential } \\
\text { Level }\end{array}$ & $\begin{array}{l}\text { Learning } \\
\text { Acuity } \\
\text { Assessme } \\
\text { nt }\end{array}$ & $\begin{array}{c}\text { Jiugongge } \\
\text { Abscissa } \\
\text { Personal } \\
\text { Performance } \\
\text { Ability-Potential } \\
\text { Report }\end{array}$ \\
\hline $\begin{array}{l}\text { Professional } \\
\text { Orientation }\end{array}$ & $\begin{array}{l}\text { Political } \\
\text { Quality }\end{array}$ & $\begin{array}{c}\text { MBTI } \\
\text { Scale } \\
\text { Evaluatio } \\
n\end{array}$ & $\begin{array}{c}\text { Individual } \\
\text { Reports and } \\
\text { Summary Reports } \\
\text { of Occupational } \\
\text { Orientation and } \\
\text { Job Matching }\end{array}$ \\
\hline
\end{tabular}

\subsection{Method of Generating Performance Level Results}

Political quality, professional ability, and performance level constitute the performance level of key talents. In the selection of evaluation methods, political quality and professional abilities are evaluated by using the 360 degree evaluation questionnaire developed by the research team, and the performance level is based on the company's annual performance evaluation results, and finally integrated and calculated as the nine-square grid ordinate-performance level. 


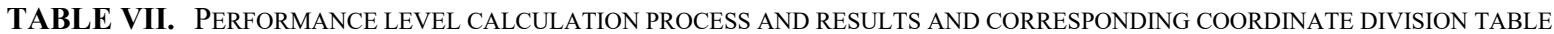

\begin{tabular}{|c|c|c|c|c|c|}
\hline $\begin{array}{l}\text { Measured } \\
\text { Index }\end{array}$ & $\begin{array}{c}\text { Evaluation } \\
\text { Score }\end{array}$ & $\begin{array}{c}\text { Assignment } \\
\text { Points }\end{array}$ & $\begin{array}{c}\text { Subitem } \\
\text { Score }\end{array}$ & $\begin{array}{c}\text { Total } \\
\text { Score } \\
\text { Interval }\end{array}$ & $\begin{array}{l}\text { Coordi } \\
\text {-nates }\end{array}$ \\
\hline \multirow{3}{*}{$\begin{array}{l}\text { Political } \\
\text { Quality } \\
\text { Professional } \\
\text { Ability }\end{array}$} & Score $\geq 85$ & 92.5 & 46.25 & \multirow[b]{2}{*}{$\geq 92.5$} & \multirow[b]{2}{*}{ High } \\
\hline & $\begin{array}{l}65 \leq \text { score }< \\
85\end{array}$ & 75 & 32.5 & & \\
\hline & Score $<65$ & 32.5 & 16.25 & \multirow{2}{*}{$75-92.5$} & \multirow{2}{*}{ Middle } \\
\hline \multirow{2}{*}{$\begin{array}{l}\text { Performance } \\
\text { Appraisal }\end{array}$} & A & 92.5 & 46.25 & & \\
\hline & $\begin{array}{l}\mathrm{B} \\
\mathrm{C} / \mathrm{D}\end{array}$ & $\frac{75}{325}$ & $\begin{array}{c}32.5 \\
1625\end{array}$ & $32.5-75$ & Low \\
\hline
\end{tabular}

\subsection{Method of Generating Results of Potential Leve}

The potential level adopts the learning acuity scale test method, and is integrated and calculated as the ninesquare grid abscissa based on the results of the scale. According to the results of the learning acuity test scale, the potential level is divided into three levels: 243 points and below are low, 243 points-324 points are medium, and 324 points or more are high. Based on this, the horizontal coordinate of the performance-potential nine-square grid is determined.

\subsection{Method of Producing Occupational Tendency Matching Degree Results}

Use MBTI scale to conduct personality test, analyze and explain the matching degree of current positions of inventory subjects, and further make correlation analysis between occupational personality test results and Jiugongge.

\section{Conclusion}

As an important means of understanding the overall situation of talents, talent inventory is of great significance to the formulation of corporate human resource strategies. Talent inventory should conduct a comprehensive and three-dimensional evaluation and evaluation of the company's talents. It is necessary to understand the ability and quality of talents, but also to pay attention to the matching degree of talents' ability characteristics and positions, loyalty to the enterprise and work performance.

\section{Acknowledgment}

This project is supported by the State Grid Corporation of China Technology Project "Research on Talent Supply and Demand Analysis Model and Supply Strategy
Research Adapting to Company Strategy" (SGSC0000KXJS2000095).

\section{References}

1. Zhu, T., "The Necessity and Process of Enterprise Talent Inventory Under the New Economic Normal," in Modern Enterprise, vol.8, Beijing , 2020, pp. 3536.

2. She, Z., "Talent Inventory Project to Enhance the Competitive Advantage of Enterprises," in Modern Business, vol.17, Beijing, 2020, pp. 31-33.

3. Han, F., "Talking About the Talent Inventory of Diversified Enterprises," in Modern Business, vol.29, Beijing, 2018, pp. 55-56.

4. Wang, T., "Talent Psychological Assessment Tools will Affect Small and Medium-sized Enterprises in Three Aspects," in Chinese and Foreign Management, vol. Z1, Beijing, 2020, pp. 47-48.

5. Wu S., "Five Steps of Enterprise Talent Inventory," in Modern Business, vol. 22, Beijing , 2017, pp. 129130.

6. Liang, X., "Inventory of Talents, Revitalizing Talents," in Enterprise Management, vol. 1, Beijing, 2020, pp. 47-48.

7. Shi, S., "Research on Talent Echelon Construction Based on Talent Inventory," in Aerospace Industry Management, vol. 6, Beijing, 2019, pp. 28-32.

8. Cheng, P., "Skillfully Use Models to Deconstruct Talent Inventory," in Human Resources, vol. 17, Beijing, 2019, pp. 46-48.

9. Yi, X., "Discuss the Application of Talent Inventory in Enterprise Talent Management," in China Small and Medium Enterprises, vol. 6, Beijing, 2020, pp. 201-202.

10. Han, F., "Talking About the Talent Inventory of Diversified Enterprises," in Modern Business, vol. 29, Beijing, 2018, pp. 55-56. 